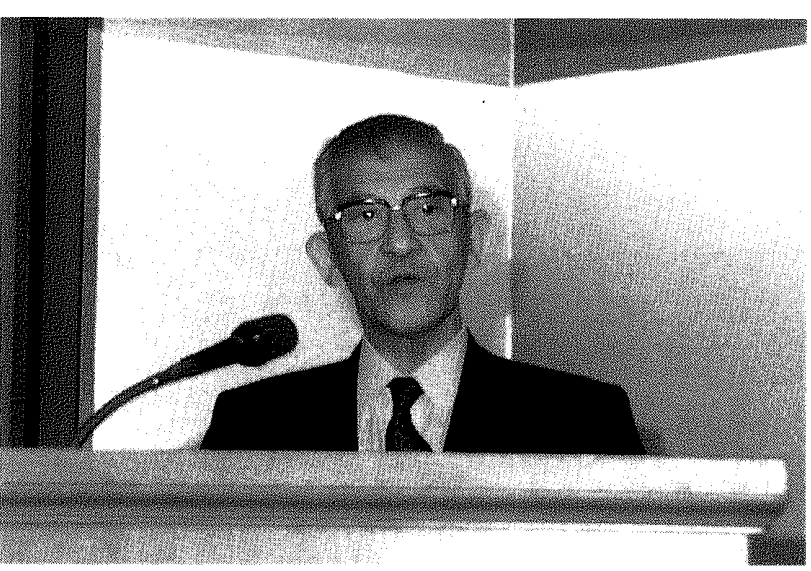

\section{〈祝 辞〉}

\section{日本医師会 会長 村瀨 敏郎}

日本医科器械学会の記念すべき創立満70周年記 念祝賀式典にあたり，日本医師会を代表して一言 ご挨拶を申し上げます。

21世紀を目前にして，わが国の医学・医療は， 急速な進歩を遂げております。その背景には，医 療技術とともに，医療機器の大いなる開発・発展 があることは，衆目の一致するところであります。 医療機器の進歩は, 単に治療の改善ばかりでなく, 患者のクオリティ・オブ・ライフ，さらに予防医 学の発展のためにも重要な役割を果たしています。

特に近年登場した衝撃波砕石装置，ガンマナイ フなど侵襲の少ない治療機器の開発，また内視鏡， M R I などに代表される検查機器の革命的な進歩 は，医師と患者にとって大いなる福音となってお ります。医療内容の改善にとって，医療技術の進 歩と医科器械の発展は, まさに事の両輪であると いえましょう。

このような医科器械の発展のなかで，日本医科 器械学会の果たしてこられた役割が，非常に大き いことは申寸までもありません，大正12年の創立 と申しますから，私ども日本医師会のほうが 7 年 ほど先輩になるわけですが，70年の長きにわたり 医科器械の進歩に取り組んでこられた多くの諸先 輩や, 現在活躍中の先生方の偉業に, 改めて大き な感銘を受けるのは私ばかりではないと思います。

日本医師会は，䀢師と患者のより良い関係をつ くり上げるために，国民の一人ひとりが“かかり つけ医”を持とうという呼びかけを行なっており ます。その実現のために矤師が医療技術の研鑚に 励むのは当然でありますが, 医科器械の進歩を認 識していくことも，必要不可久になっております。

日本医科器械学会が70周年を契機に，ますます 大きな飛躍を遂げ，医療社会に貢献されますこと を祈念し，祝辞と致します。

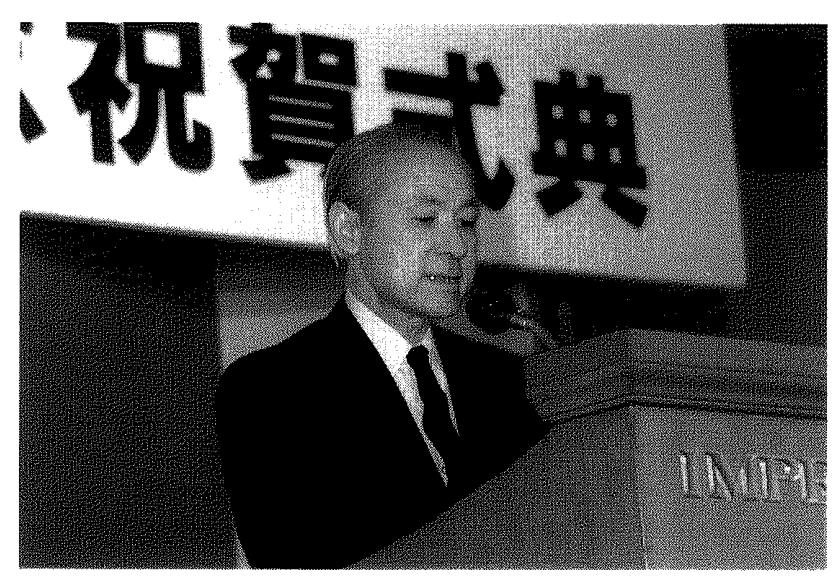

亘

本日, 日本医科器械学会の創立満70周年の記念 式典に当たり，日本医学会会長として，一言，抒 祝いを申し上げます。

日本医科器械学会は, 医科器械にかかわる諸般 の事項を研究することによって, 医学の進歩発達 を四ることを目的として，大正12年 3 月に設立さ れ, 大正 15 年, 第 7 回日本医学会総会の機会に, 第34分科会として日本医学会に加入されました。

日本医科器械学会は, 日本医学会の他の多数の 分科会とは異なって, 設立当初から医学研究者だ けでなく, 理工学者, 医療機器メーカーの 3 者が 渾然一体となって構成され，会員構成において極 めて特貲な立場をとっているのであります。

いうまでもなく，医学と医療に医療機器は不可 欠でありますが, 医科器械の進歩は医学者だけに よって行なわれ得るものではなく，理工学者，䀢 科器械メ一力ーの密接な協力を得てこそ初めて達 成できるものであります。

すでに70年前, この理念を確立して日本医科器 械学会を設立された先覚者の慧眼と，その理念を 継承して今日の隆盛を築かれた会員各位のご努力 に，襄心から敬意を表し，今日，ここに70周年の 記念すべき日を迎えられたことを，心からお慶び する次第であります。

また 4 年ごとに開催される日本医学会総会の折 には，回を逐ってますます盛大に赴く総合医器展 の企画と運営にご尽力をいただき，日本医学会の 興隆のために多大のご貢献を賜つていることは, 日本医学会として, 感謝に㙋えないところであり ます。

どうか今後も, 日本医学会の重要な分科会の一 つとして, 人類の健康と福祉のために一層の発展 を成し遂げられ，10年後には今回にもまして，更 に盛大な80周年を祝賀されることを祈念して，祝 辞とする次第であります。 